\title{
Peran Gereja Dalam Regenerasi Pemimpin Rohani Masa Kini
}

\author{
Henos Kassi, ${ }^{1}{ }^{*}$ Ervi Johan Lo, ${ }^{2}$ Sabar Manahan Hutagalung,${ }^{3}$ David Martinus Gulo ${ }^{4}$ \\ Prodi Teologi, STT Real Batam \\ Prodi Teologi, STT Real Batam \\ Prodi Teologi, STT Real Batam \\ Prodi Teologi, STT Real Batam \\ henoskassi03@gmail.com
}

\begin{abstract}
The role of the leader to date has a great influence from various aspects even very important and needed by many people. Today many leaders fail to form young leaders or fail to regenerate spiritual leaders today. So that no one continued the service they had built and as a result the campaign was closed. In this journal, it will be presented as the role of the leader in forming the present spiritual leader. And it will also show that the current spiritual leaders are worthy of becoming a real leader. And what should they do when they become the real leaders. The goal of this journal is how the success of a leader is measured by the ability to produce spiritual leaders today.
\end{abstract}

Keywords: Role, Leader, Regeneration, Spiritual, Present

\begin{abstract}
Abstrak
Peranan pemimpin sampai saat ini memberikan pengaruh yang besar dari berbagai aspek bahkan sangat penting dan dibutukann oleh banyak orang. Saat ini banyak pemimpin yang gagal dalam membentuk pemimpin muda atau gagal mengkaderisasiakan pemimpin-pemimpin rohani masa kini. Sehingga tidak ada yang melanjutkan pelayanan yang sudah dibagunnya dan berakibat pelanyana tersebut ditutup. Dalam jurnal ini akan disajikan sebagaiman seharusnya peranan pemimpin itu dalam membentuk pemimpin rohani masi kini. Dan juga akan menunjukan kareteria pemimpin rohani masi kini yang layak menajdi seorang pemimpin sesungguhnya. Dan apa yang harus mereka lakukan ketika mereka sudah menjadi pemimpin yang sesunggunya. Gol dari jurnal ini adalah bagaimana kesuksesan seorang pemimpin di ukur dari ia mampu melahirkan pemimpinpemimpin rohani masa kini.

Kata kunci: Peran, Pemimpin, Regenerasi, Rohani, Masa Kini
\end{abstract}

\section{PENDAHULUAN}

Kepemimpinan adalah pengaruh, yaitu kemampuan seorang untuk mempengaruhi orang lain. Pemimpin yang terombang ambing tidak akan pernah mampu menjadi pemimpin dalam jangka panjang. Karena pemimpin sangatlah di perlukan untuk menangani setiap masalah yang ada disetiap organisasi. Terlebih masalah dalam meregenerasi pemimpin untuk memimpin dimasa depan sangat berpengaruh. Seseorang yang diangkat menjadi pemimpin rohani berarti berbicara tentang individu atau pribadi yang dipilih untuk melaksanakan atau menggantikan tugas kepemimpinan yang telah dipimpin untuk waktu yang singkat sampai waktu yang panjang. "Pemimpinpemimpin rohani tidak dihasilkan oleh pemilihan atau pengangkatan, baik oleh manusia atau sekelompok orang, 
maupun oleh konperensi atau sinode. Hanya Tuhan yang dapat menghasilkan pemimpin rohani."1

Gaya kepemimpinan sangatlah memberikan dampak pada sebuah oraganisasi yang sedang berjalan. "Seperti orang yang di utus kemedan perang yang sepenuhnya tunduk kepada pemimpin perang. Karena itu tugas pemimpin gereja (gembala), khususnya mereka yang memiliki karunia-karunia mengajar." Dalam rangka membentuk pemimpin rohani masa kini, seorang pemimpin harus bisa melihat pengikutnya yang akan di latih untuk menjadi pemimpin, apakah penyerahan diri dan tingkat kerohanianya itu dekat dengan karakter seorang pemimpin. Jadi lamanya anggota menjadi seorang pengikut bukanlah tolak ukur pemimpin untuk menjadikan dia sebagai pemimpin rohani masa kini, namun tingkat kerohanianya, integritas kepemimpinannya, dan kedewasaan dalam mengambil keputusan dan memberikan arahan kepada anggota lainya.

Seorang pemimpin rohani (Gembala) yang memiliki aktifitas lain, selain penggembalaan di gereja lokal membuat kami mengangkat judul "Peranan kepemimpinan dalam regenerasi pemimpin rohani masa kini”. Sehingga perlu disadari bahwa kurangnya pemimpin menciptakan kurangnya pengikut dan kurangnya pengikut menghasilkan kurangnya para pemimpin masa depan. Hal ini tepat seperti yang penjelasan Fredy Simanjuntak, Banyak gereja berhenti bertumbuh secara jumlah pada titik tertentu karena tidak mengembangkan kepemimpinan yang cakap dan cukup untuk melayani anggotaanggota baru. Gereja cenderung membiarkan struktur organisasi dan manajemennya membatu. ${ }^{2}$

Tujuan penulisan adalah, pertama agar para membaca dapat mengerti bahwa tantangan seorang pemimpin ketika mengerjakan aktivitas lain selain diluar penggembalaan di gereja lokal, sangatlah berdampak kepada pertumbuhan rohani jemaat. karena itu seorang pemimpin harus melakukan pemuridan kepemimpinan dalam bidang kerohanian. Dengan tujuan bisa menggantikan posisi kepemimpinannya ketika berada diluar daerah dan dimasa mendatang. Kedua agar pemimpin mampu menjelaskan begitu pentingnya menjadi seorang pemimpin dalam menjalankan organisasi yang kecil maupun yang besar. Mendorong dan memberikan pengajaran-pengajaran kepada anggotaanggota organisasi terkhusus pemimpin yang telah disiapkan agar mampu menjadi pemimpin rohani masa kini dan menjadi pemimpin bagi sekitarnya. Memberikan pengajaran-pengajaran yang bersifat kepemimpinan agar mental dan kerohanian mereka terbentuk. Organisasi tetap bertumbuh sekalipun pemimpin tidak dilokal maupun pemimpin telah berganti.

\footnotetext{
${ }^{1}$ J. Oswald Sanders, Kepemimpinan Rohani (Bandung: Kalam Hidup, 1979).11

${ }^{2}$ Fredy Simanjuntak, "Kecerdasan Emosi Pemimpin Sebagai Tolok Ukur Gereja Yang Sehat," Real Didache 2, no. 1 (2017): 29-53.
} 


\section{METODE}

Untuk mengetahui peran dari seorang pemimpin dalam mengkaderisasikan pemimpin rohani masa kini dinyatakan dalam tujuan penelitian, maka digunakan Metode wawancara dalam bentuk percakapan. Metode wawancara adalah salah satu cara untuk mengumpulkan informasi yang tepat dan akurat, sehingga bersifat sistematis dan logis. Dalam penelitian ini penulis mengunalan metode kualitatif karena dianggap lebih mudah untuk dipahami dan banyak referensi buku yang mendukunya, dan juga tidak menimbulkan penekanan pada angka-angka.

\section{HASIL DAN PEMBAHASAN}

\section{Pengertian Pemimpin}

Pemimpin adalah seorang yang mampu mempengaruhi orang lain. Setiap orang yang berpengaruh pasti akan menjadi teladan. "Ketika seseorang menjadi teladan yang baik, hubungannya dengan orang lain itu cukup dekat untuk melihat teladannya. Dan memberi penjelasan pada saat-saat yang tepat pada orang lain untuk mengerti." 3 Setiap orang yang sudah dipengaruhi oleh orang lain, maka orang yang berpengaruh ini akan menjadi seorang pemimpin.

"Pemimpin yang baik memberikan nyawanya bagi jemaat-jemaatnya. Sebagai jemaat yang siap untuk memjadi sorang pemimpin rohani, ia harus menyediakan waktu kunjungan dan bergaul dengan baik dengan jemaat, menyediakan waktu untuk memikirkan dan mendoakan jemaat."

Pemimpin harus mampu menjadi seorang yang optimis namun tidak pesimis. Menerima pemikiran orang lain, tapi tidak terpengaruh oleh pemikiran orang lain. yang terpenting pemimpin harus memiliki hubungan dan modal untuk mengajar sehingga menjadi teladan. Ketika pemimpin memiliki hubungan, mengajar, dan menjadi teladan maka pemimpin tersebut menjadi pengaruh.

\section{Peran Pemimpin}

"Penegasan paulus bahwa cita-cita untuk menjadi seorang pemimpin adalah suatu keinginan yang mulia, tidak akan diterima oleh semua orang Kristen dengan begitu saja."

Menjadi pemimpin adalah suatu cita-cita yang sangat mulia, namun citacita menjadi pemimpin bisa menjadi sebuah ambisi. Dimana ada ambisi-ambisi yang mulia yang pantas untuk dihargai dan patut dikejar. Tetapi dibalik ambisi yang mulia tersebut, ada ambisi yang memiliki ego yang tak disadari sehingga bisa menjadi sebuah kesombongan dan sifat yang angkuh. Maka setiap pemimpin rohani harus mengerti, mehami dan melakukan Firman Tuhan supaya dapat mengerti bahwa pemimpin tidaklah menghendaki jabatan.

\footnotetext{
${ }^{3}$ David Mays, Bagaimana Menjalankan Tim Kepemimpinan Misi Yang Efektif,(Indonesia)Hal. 24 (Bandung: Yayasan Mitra Pengembangan Desa, 1999). 24

${ }^{4}$ Sanders, Kepemimpinan Rohani.9
} 
Peranan pemimpin sangatlah penting bagi para anggota organisasi bahkan bagi para murid yang telah dipersiapkan menjadi seorang pemimpin dimasa yang akan datang. Sifatsifat kepemimpinan yang alamiah juga penting dalam kepemimpinan rohani, sehingga pemimpin harus mengetahui potensi kepemimpinan alamiah yang dimiliki para murid yang telah dipersiapkan. Karena pertobatan tidak sepenuhnya membuat orang menjadi pemimpin, hanya ada orang yang dipenuhi Roh Kudus sehingga dia menerima karuniakarunia rohani yang menambah potensi kepemimpinan bagi penerimanya.

Adapun peran penting yang harus dilakukan oleh seorang pemimpin untuk melatih muridnya menjadi pemimpin rohani masa kini yaitu:

Menunjukkan Jalan

Seorang pemimpin selalu menunjukkan jalan yang benar dan baik untuk para muridnya. Para pemimpin harus mampu mendorong muridnya untuk dapat melakukan hal yang lebih besar dari dirinya. Semua hanya bertujuan untuk kemulyaan Kristus dan kemajuan organisasi yang dipimpinnya.

Menjadi Contoh

Pemimpin menjadi sebuah contoh yang nyata dalam sebuah pemuridan. Sehingga para murid selalu melakukan apa yang telah dilakukan pemimpinnya dalam sebuah praktek kepemimpinan dan kehidupannya.

Pemimpin yang meberikan contoh yang benar dan baik dihadapan Tuhan, akan menciptakan pemimpin baru yang takut akan Tuhan dan yang siap untuk menjadi pemimpin yang lebih dari pemimpinnya. Sehingga organisasi yang dipimpin akan terus bertumbuh, berkembang, dan berhasil karena ada pemimpin-pemimpin baru masa kini yang telah dipersiapkan dan diperlengkapi.

Melibatkan Diri

Setiap pemimpin harus melibatkan diri pada pemilihan, pengajaran dan memperlengkapi pemimpin rohani yang telah dipersiapkan.

Pemilihan

Pemimpin harus memilih anggota yang telah dipersiapkan sesuai kriteria seorang pemimpin. Yaitu :

Yakin dengan Panggilanya

Syarat menjadi seorang gembala diawali dengan meyakini terlebih dahulu bahwa panggilan yang sudah Tuhan tetapkan pada dirinya adalah memang benar untuk mengemban tugas penggembalaan.

\section{Lahir Baru}

Seorang gembala harus melihat jemaat yang akan dijadikan pemimpin rohani harus melihat apakah jemaat tersebut sudah lahir baru dalam arti ia sudah dibabtis air maupun 
roh. Dan jemaat tersubut benarbenar meninggalkan masah lalunya dan menjadikan kristus tujuan hidupnya. ${ }^{5}$

Suka Berdoa

Pridadi yang berkualitas adalah pribadi yang memiliki kehidupan doa. Dalam artian jemaat yang suka berdoa memiliki hubungan dekat dengan Tuhan yang kerohaniaanya sudah terbentuk.

Dewasa Dalam Mengambil

Keputusan Dalam mengambil keputusan harus dengan kepala dingin artinya harus berhati-hati, agar keputusan yang diambil tidak salah dan tidak menyebabkan kerugian. Maka dari itu pentinglah sikap dewasa dalam mengambil keputusan agar tidak gegabah dalam mengambil keputusan, dan tidak menyesal akibat keputusan yang telah diambil.

Memiliki Integritas

Anggota yang akan dijadikan sebagai pemimpin rohani masa kini harus melakukan dan mengucapkan hal yang benar. Yang dimana jemaat tersebut mampu mempraktekkan kebenaran firman Tuhan, ia mampu berkata jujur, karena orang yang memiliki integritas akan utuh dan tidak akan pernah rusak gambar diri, karena itu anggota yang dipilih menjadi seorang pemimpin rohani harus memiliki integritas.

\section{Pengajaran}

Pengajaran sangat mempengaruhi kepemimpinan para anggota yang sedang dipersiapkan. Maka pemimpin harus mengajarkan cara memimpin yang benar, yaitu pemimpin menegur sebagai Seorang Bapa dan pemimpin yang mengasihi jemaat.

\section{Memperlengkapi Pemimpin Masa Kini}

Pemimpin harus memperlengkapi anggota yang telah dipersiapkan untuk memimpin dimasa depan. Pemimpin harus menjelaskan apa saja yang menjadi tugas dan tanggung jawab sebagai pemimpin. Pemimpin harus mengajarkan bahwa seorang pemimpin rohani selalu mengajarkan pengajaran yang benar kepada jemaat supaya Iman yang dimiliki jemaat terus bertumbuh dan berkembang. Kemudian tugas seorang pemimpin adalah memberitakan injil dan mempersiapkan regenerasi pemimpin selanjutnya.

\section{Pemimpin Rohani Masa Kini}

Perlu diketahuai bahwa seorang pemimpin harus mampu dan mau untuk berada didepan dan memimpin jalannya, memiliki inisiatif, keberaniaan, dan iman. Seorang pemimpin yang disiapkan harus mengetahui otoritas yang diberikan Tuhan kepadanya sehingga setiap otoritas yang dimiliki harus dikembangkan. "Tujuan utama dalam

\footnotetext{
${ }^{5}$ Dick Iverson and Larry Asplund, Gereja Sehat Dan Bertumbuh (Malang: Gandum Mas, 2003).34
} 
pengembangan otoritas adalah membantu seorang pemimpin memahami bahwa otoritas rohani adalah dasar utama otoritas bagi pengaruh kepemimpinan." 6

Seorang pemimpin itu harus memiliki kemampuan untuk memberikan inspirasi bagi yang lainnya, dan juga memiliki karakter yang membuat orang lain ingin mengikutinnya. Dan yang tidak kalah penting dari seorang pemimpin ialah bagaimana ia memiliki kemampuan untuk memotifasi orang lain, untuk berjalan kejalan yang benar. Pemimpin rohani masa kini lebih bercorak kepada kepemimpinan yang hanya mengenal istilah maju. Dia bergerak menuju sasaran yang pasti dan tidak merugikan/menghancurkan sekelilingnya khususnya anggota jemaat lainnya yang telah bertumbuh.

Dari materi yang kami bahas implementasi yang dapat mereka terima adalah mereka akan memehami terlebih dahulu menjadi seorang pemimpin bukanlah suatu hal yang mudah. Mereka akan terus belajar menjadi sosok pemimpin yang bukan hanya sekeaar memberi dampak namun apakah dia mampu menjadi seorang pemimpin yang membentuk pemimpin baru sebagi regenerasi dalam pelayanan yang sudah ia kerjakan. Implementasi yang akan di terima oleh seorang pemimpin ketika membaca makalah ini. Mereka akan mengerti bahwa pelayanan yang dia bangun selama ia hidup itu hanya akan sia-sia saja apabila tidak ada regenerasi dari keturunannya. Maka dari itu seorang pemimpin pasti tidak akan tinggal diam saja, ia pasti mulai berfikir bagaimana cara agar pelayanan yang sudah ia bangun itu tetap jalan sekalipun pemimpin tersebut sudah pensiun atau meninggal.

\section{KESIMPULAN}

Dalam penjelasan jurnal saya ini, penulis mengambil kesimpulan bahwa peran seorang pemimpin dalam membentuk pemimpin rohani masa kini bukanlah hal yang mudah, dimana seorang pemimpin harus melihat terlebih dahulu kualitas anggota jemaat yang akan dibentuk sebagai seorang pemimpin. Untuk gembala yang mempunyai aktifitas diluar gereja lokal, Harus tetap memperhatikan pertumbuhan kerohaniaan jemaat yang akan ditinggalkan ketika ia keluar. Karena itu Gembala harus memiliki metode-metode yang tepat untuk memilih beberapa dari anggota jemaat untuk dijadikan pemimpin rohani masa kini untuk menggatikan posisinya sebagai pemimpin (gembala). Karena itu untuk seorang Gembala harus memastikan apakah anggota jemaat yang dipilih itu sudah siap untuk dijadikan pemimpin. Dan menjadi seorang pemimpin bukanlah hal yang mudah. Karena kenapa? Ia akan di bebankan tugas pelayanan yang besar dan berat, ia harus mampu memiliki dan mewarisi sikap dari seorang gembala. Seorang pemimpin rohani harus bisa menjadi terang dan pelaku Firman Allah di tengah-tengah jemaat. Dan seorang pemimpin rohani harus memiliki kerohaniaan yang dekat dengan Tuhan.

\footnotetext{
${ }^{6}$ J. Robert Clinton, Pembentukan Pemimpin Sejati (Jakarta: Metanoia, 2004).64
} 


\section{KEPUSTAKAAN}

Clinton, J. Robert. Pembentukan Pemimpin Sejati. Jakarta: Metanoia, 2004.

Iverson, Dick, and Larry Asplund. Gereja Sehat Dan Bertumbuh. Malang: Gandum Mas, 2003.

Mays, David. Bagaimana Menjalankan Tim Kepemimpinan Misi Yang

Efektif,(Indonesia)Hal. 24. Bandung: Yayasan Mitra Pengembangan Desa, 1999.

Sanders, J. Oswald. Kepemimpinan Rohani. Bandung: Kalam Hidup, 1979.

Simanjuntak, Fredy. "Kecerdasan Emosi Pemimpin Sebagai Tolok Ukur Gereja Yang Sehat." Real Didache 2, no. 1 (2017): 29-53. 